\title{
Intellectual Property Rights in Legal Perspective in Indonesia
}

\author{
Fauzan Indra $^{1}$, Faisal Santiago ${ }^{2}$ \\ \{fauzanunbor@gmail.com ${ }^{1}$, faisalsantiago@borobudur.ac.id²\} \\ Universitas Borobudur, Jakarta, Indonesia ${ }^{1,2}$
}

\begin{abstract}
Creativity and productivity in creating works provide an opportunity to be able to patent into Intellectual Property Rights. The development and progress of science and technology offer a broad space in developing the potential for the creation of something new. However, the protection of Intellectual Property Rights is still a problem in Indonesia. Through a normative juridical approach accompanied by data collection through literature found that the state needs to protect Intellectual Property Rights, based on justice and balance. This protection is functional for respecting intellectual property but still provides a balance so that monopolistic practices do not occur in the community.
\end{abstract}

Keywords: Intellectual Property Rights; Protection; Guarantee

\section{Introduction}

In simple terms, intellectual property (IP) is a property that arises or arises from human intellectual abilities. Works that occur or emerge from human intellectual capabilities can be in the form of deeds in technology, science, art, and literature fields. These works are born or produced from human intellectual capacity through the outpouring of time, energy, thought, creativity, taste, and intention. It distinguishes intellectual property from other types of wealth that can also own by humans but are not produced by human reason. For example, natural wealth in the form of land and/or plants found in nature is the Creator's creation. Although the earth and/or plants may belong to humans, they are not the product of human intellectual creation. Wealth or wealth in the form of works arising from the human mind or intelligence has economic value or benefits for human life, so it can also be considered as a business asset. Creations born or produced based on human intellectual abilities, either through the growth of energy, thought and creativity, taste, and intention, are naturally ensured by the development of a legal protection system for such property, known as Intellectual Property Rights (IPR) or IPR system [1]. IPR is a means to protect intellectual property by using existing legal instruments, namely copyrights, patents, trademarks and geographical indications, trade secrets, industrial designs, layout designs, integrated circuits, and protection of plant varieties.

Intellectual property rights are personal rights for everyone who creates an intellectual work. That is where the characteristic of IPR is that a person is free to submit or not submit or register his intellect work. The exclusive rights granted by the state to individual IPR actors (inventors, creators, designers, etc.) are intended to enhance the work (creativity) and 
encourage others to develop it further. The community interests are determined by the market mechanism [2]. In addition, the IPR system supports the creation of a great documentation system for all forms of human creativity so that the possibility of producing the same technology or other works can be avoided/prevented. It hopes that the community can make maximum use of it for their daily needs or develop it further to provide more added value supported by excellent documentation. The problem of IPR is a problem that continues to grow and follows the development of science and technology (IPTEK). Intellectual property rights have become a vital element for a country to maintain its industrial and commercial advantages. During the competition in the industrial world in an era of turmoil, it is crucial to be able to provide guarantees to IPRs so that there is no monopoly by some parties. This document aims to provide a comprehensive overview of the protection of intellectual property rights by the Indonesian government.

\section{Methodology}

The methodology used in this research is normative research [3], which will use descriptive research with a normative juridical approach, based on applicable laws and regulations [4]. By using secondary data as a normative research approach that seeks and uses library materials such as scientific writings and scientific journals, books on Intellectual Property Rights.

\section{Results and Discussion}

Economic development in today's world cannot be separated from the IPR system, in everyday life, has been recognized how great the influence of human intelligence is. The results of human genius with the produced intellectual work have contributed a lot to help us live a better life. This can be seen from the environment or from the house we live in, various household appliances, clothing, electronics, communication, transportation, office equipment, and others are the result of human intellectual work that greatly helps human life in carrying out its activities [1]. Therefore, to encourage other beneficial creations, it is crucial to stimulate those who create or invest in the creation of spiritual works. Developed countries have recognized the need for incentives for centuries by establishing a system in which new or original intellectual work is treated as a property known as intellectual property.

Intellectual property accelerates the economic development of a nation. Not only the quality of intellectual property but also the transfer of technology and knowledge will improve by the establishment of intellectual property protection for those who create intellectual works or invest in the creation of intellectual works. Developed countries Intellectual property rights are not only a legal instrument used only to protect someone's intellectual work, but also used as a business strategy tool to commercialize an invention. State awards in granting monopoly rights to producers of intellectual works allow intellectuals to economically exploit their inventions [5]. Incentives for intellectual property rights holders in the form of a monopoly are intended so that producers of intellectual works can use or utilize their intellectual property within a certain period. A monopoly over the use and benefit of intellectual property allows rights holders to receive income and profits for the time, money, and effort they put into creating intellectual property. With sufficient income, rights holders can invent an even better intellectual property. 
The rights of the creators of intellectual works are not only in the form of economic rights but also in the form of moral rights that maintain the integrity of the intellectual works produced. In addition, there are social benefits in the form of diffusion, enrichment, and government support for the development of the IPR system [1]. The intellectual property rights system is expected to play a role in building a culture that can transform the user community into a society that develops its potential to give birth to new creators, inventors, and designers. To compete in the world market, industry players must know and follow the commercial regulations developed and implemented in the destination country, including those concerning intellectual property rights. Customs in some countries also require that IPR documents can be attached to mandatory documents and additional documents. Lack of understanding of the regulations of the destination country can cause difficulties for Indonesian products, especially when entering foreign markets, and if the product is successful, then the risk of being sued by the holder of intellectual property rights of a product in foreign markets is very high.

The growing perception of property rights in intellectual works ultimately also raises the need to protect or defend them from others. The concept of legal protection for intellect works arises from this need. It is a journey from intellectual property to the legal system. Legal protection, monopoly rights, or exclusive rights for people who can produce intellectual works are considered to help in maintaining the peace of rights holders from interference from others so that they can enjoy the maximum economic benefits from hard work Changing and encouraging others to do so, to work hard, to compete. Based on this, a person participating in the exploitation of profits without the consent of the intellectual property owner is considered an infringement. Intellectual property is an abstract right compared to the ownership of tangible objects, but these rights are closer to property rights, and both are absolute. It is because rights, which are abstract after leaving the human mind, then become literary, scientific, or artistic creations, computer programs, symbols, technological inventions, trade secrets, designs, or finally tangible objects (lichamelijke zaak), exploitation (exploitation), and what kind of reproduction that can be a source of profit.

That justifies the classification of these rights under property law. Based on their nature, intellectual property rights are classified as property rights to intangible assets. The concept of extending property rights from only tangible assets to intangible assets is intended to allow for the justification of intellectual property rights as subject to criminal theft or counterfeiting. At first, IPR violations could not be criminalized in Indonesia. Even in the United States, the country that pioneered the enforcement of intellectual property rights worldwide before the Trademark Counterfeiting Act of 1984 came into effect in the United States Congress, still believes that this form of trademark ownership cannot be construed as a criminal act that meets the elements of the crime of theft or forgery [6].

The State's commitment to protecting the intellectual property rights of its citizens can arise because this intellectual property instrument is essentially an instrument that does not want to appreciate the work of the human mind wherever it comes from in the development of intellectual property only or economic value for the beneficiary, but also a sizable benefit for the State. In 1993, an investigation by Stichting Voor Economische Onderzoek (SEO) at the University of Amsterdam showed that the copyright industry not only increased gross domestic product but also the number of local workers. Another study showed that the valueadded of the copyright industry was estimated at twenty billion guilders in 1989 .

Indeed, what has proven to be effective in Indonesian society is what some experts previously feared, where the entry of intellectual property rights into the Indonesian legal system has created problems in society. According to Sri Rejeki Hartono, the perspective on 
intellectual property rights that seems to answer global challenges is a negative perspective on society. That is caused by several factors such as community cultural factors, lack of attention to property rights, lack of order in the maintenance of own property, and collective society. In addition, there are weak law enforcement factors, relatively very limited legal training, lack of responsiveness from the authorities, and the inability or lack of agile actions from those responsible and relevant to the enforcement of intellectual property rights.

The introduction of intellectual property rights as intangible individual property rights and their direct elaboration in a definite legal order, especially in economic life, is a new thing in Indonesia. As a legal system, Intellectual Property Rights (IPR) has not experienced an increase in the legal system since its inception in Indonesia. Its presence also complements the concept of property rights in Indonesian civil law. As will be clear, the notion of property rights known in civil law and force to this day depends on the notion of materiality. Moreover, this concept also relies heavily on physical assumptions, namely nature/soil and other objects contained or cultivated in it. Even if later developed on the assumption of non-physical or intangible, these rights are still derivatives of rights that arise from the material concept. The second book on the material of the Civil Code that has been applied so far shows all of it. The entire contents of Book Two do not consider any property rights arising from or arising from the intellectual abilities of the person himself.

In addition, the culture of mutual cooperation is one of the characteristics of Indonesian society, this value has given birth to the concept of own property rights. For Indonesian people, property rights have a social function that can also be carried out by others. For the most part, Indonesian people, especially IPR holders, until now do not consider their intellectual property rights to be used or exploited by others, while intellectual property rights themselves are not Indonesian cultural values, but western values regulated in the legal system. Therefore, the application of intellectual property rights in people's lives creates conflicts with traditional cultural values that are institutionalized in people's lives and also creates a big "culture shock". Moreover, if there is an act that is qualified as a crime in the concept of intellectual property rights, but in the cultural values of the community, it would not be considered as a crime. This culture shock will affect the awareness, appreciation, respect, and enforcement of intellectual property rights in society. This condition is aggravated by a mentality that underestimates quality, a penetrating mentality, self-doubt, and a mentality that likes to ignore responsibilities that grow in Indonesian society.

Intellectual Property Rights (IPR) thus aim to improve the protection and law enforcement of IPRs related to trade in goods and services and strengthen regulations on counterfeit products. The TRIPS Agreement (Trade-Related Aspects of Intellectual Property Rights, including the Trade in Counterfeit Goods) requires member states to comply with the TRIPS Agreement but provides freedom to determine how it "applies following member countries' practices and legal systems. As such, The TRIPS Agreement provides legislative options that can give developing and least developed countries the opportunity to enact intellectual property rights laws as needed. Furthermore, the TRIPS Agreement states that the Member States may adopt or amend their laws and regulations to create the necessary protections for community health and nutrition and to support the public interest in vital sectors essential to socio-economic and technological development.

Intellectual Property Rights (IPR) disputes in Indonesia are only resolved through civil and criminal channels. The Civil Code contains questions about cancellations (patents) which can be divided into two parts which are cancellation by law (due to non-payment of annual fees) and cancellation, namely cancellation at the request of the competent authority. IPR itself or 
by other parties. Cancellation for legal reasons means no process is needed, the decision is taken directly by the Directorate General of Intellectual Property Rights (DGIP).

\section{Conclusion}

The IPR legal system is intentionally used as a monitoring tool to break down or break down the barriers of space and time, which have been used as an excuse by developing countries to regulate their laws, which are often considered obstructive or incompatible. with the economic interests of developed countries. Transplantation of the legal system of intellectual property rights, which moreover emerges from an individualistic culture where property rights to an intellectual work must receive exclusive legal protection, into Indonesian society which has a basic and cooperation culture, where property rights over an object which has a social function, coupled with the lack of an appreciative culture in intellectual work, as well as the large number of people who have a profit mentality, have created a culture shock that opens up many opportunities or spaces for emergence "waves" of conflict in society.

\section{References}

[1] K. Setyowati, “ Implementation of the intellectual property rights (IPR) system in the management of germplasm," 2002.

[2] R. L. (ed. ). Abel, Ed., The Law and Society. New York: New York University Press, 1995.

[3] M. H. Dr. johnny ibrahim,SH., Teori \& Metodologi Penelitian Hukum Normatif. 2006.

[4] J. Ibrahim, "Normative Legal Research Theories and Methods," Bayu Media, Malang, 2006.

[5] Stern JE \& Elliot D, The Ethics of Scientific Research. Hanover \& London: University Press of New England, 1997.

[6] D. J. Bainbridge, Cases \& Materials in Intellectual Property Law. London: Piman Publishing, 1995. 